\title{
Can sales of infested timber be used to quantify attacks by Ips typographus (Coleoptera, Scolytidae)? A pilot study from Belgium
}

\author{
Anne FrAnKLIN ${ }^{\mathrm{a}, \mathrm{b} *}$, Charles De CANNIÈRE ${ }^{\mathrm{a}}$, Jean-Claude GRÉGOIRE ${ }^{\mathrm{a}}$ \\ ${ }^{a}$ Lutte biologique et Écologie spatiale, Université Libre de Bruxelles, 1050 Bruxelles, Belgium \\ b Current address: Royal Belgian Institute of Natural Sciences, Dept. Invertebrates, rue Vautier 29, 1000 Bruxelles, Belgium
}

(Received 16 August 2002; accepted 3 June 2003)

\begin{abstract}
Quantifying the abundance and distribution of forest pests is a widespread problem in forest health management. Bark beetles are monitored using a number of methods, including damage surveys and pheromone trapping. As such methods are expensive and timeconsuming, information is also regularly compiled from estimations of the number of infested trees removed from the forest. The reliability of those estimations is poorly documented. This pilot study investigated whether data from sales of attacked trees from public forests could be used for the assessment of Ips typographus infestations in Belgium. Results of the study indicated that local forest officers showed sufficient expertise in identifying and reporting attacks, but sometimes overestimated attack levels. Despite some limitations, such as the need to avoid working per flight season or with quantitative estimations of the number attacked trees, sales records can be reliably used to identify stands infested by I. typographus.
\end{abstract}

Ips typographus / Scolytidae / attack levels / timber sales / pest management

Résumé - Les ventes de bois infesté peuvent-elles être utilisées pour quantifier les attaques de scolytes ? Une étude de cas en Belgique. La quantification de l'abondance et de la distribution des ravageurs forestiers est un problème répandu dans le cadre de la gestion de la santé des forêts. Le suivi des scolytes est effectué à l'aide de différentes méthodes, notamment par l'examen des dégâts et le piégeage par phéromones. Comme ces méthodes peuvent être onéreuses et lourdes à mettre en œuvre, l'information est aussi souvent obtenue à partir d'estimations provenant du nombre d'arbres infestés enlevés de la forêt. La fiabilité de des estimations est mal documentée. Cette étude préliminaire a examiné si les ventes de bois infestés des forêts soumises pouvaient être utilisées pour estimer les niveaux de population d'Ips typographus en Belgique. Les résultats de l'étude ont montré que les agents forestiers avaient une expertise suffisante pour l'identification et le rapportage des attaques mais surévaluaient parfois les nombre d'arbres attaqués. Malgré certaines limitations, comme la nécessité d'éviter une comptabilisation sur base des saisons de vol ou sur base d'estimations quantitatives du nombre d'arbres attaqués, les données des ventes de bois peuvent être utilisés de manière fiable pour identifier les peuplements attaqués par I. typographus.

Ips typographus / Scolytidae / niveaux d'attaques / vente de bois / gestion des ravageurs

\section{INTRODUCTION}

There are many different methods for measuring forest pest populations. In the case of bark beetles, techniques include damage assessments on individual trees, follow-up of permanent plots, aerial surveys, pheromone trapping of adult insects or questionnaires sent to foresters [2, 8,9]. A few countries, like France and Finland, have made a thorough evaluation of their monitoring methodology $[6,8]$ but nearly no information is available on the quality of statistics compiled from the removal of infested trees from the forest, even though they are regularly used to estimate pest status [see references in 4].
One of the most important pests in Belgium is the spruce bark beetle Ips typographus (Coleoptera, Scolytidae). It can cause considerable damage to Norway spruce (Picea abies). Knowledge of population levels is crucial to detect emerging outbreaks quickly. Some information on attacks by I. typographus can be obtained from Wallonia's permanent forest inventory [6], but the collection of data is slow as a full cycle of the inventory takes 10 years to be completed. An alternative method is needed for a rapid assessment of infestations. In this paper, we evaluate whether data from sales of attacked timber can be used to describe the occurrence of I. typographus in southern Belgium.

\footnotetext{
* Corresponding author: anne.franklin@ naturalsciences.be
} 
Table I. Information provided on the timber-marking forms used by the forest administration in Wallonia. Each form records the characteristics of trees sold in a given timber consignement.

\begin{tabular}{ll}
\hline Field & Description \\
\hline Owner & Landowner (state, city council, province, etc.) \\
Locality & Name of the place of felling \\
Compartment & Compartment and plot number \\
Species & Tree species \\
Date & Date of the marking of the trees to be felled \\
Operation & Type of felling operation (clearcuts, thinnings, etc.) \\
Quality & Quality of the trees (healthy, dead or dying, windthrows, broken) \\
Bonus-malus & Bonus or penalty given to the trees' commercial value, depending on their quality, in \% of the commercial value \\
Number & Number of trees in each circumference category \\
Circumference & Circumference categories, ranging from $25 \mathrm{~cm}$ at breast height (1.50 m in Belgium) to $295 \mathrm{~cm}(5 \mathrm{~cm}$ steps) \\
Height & Average height of the trees in each circumference category (visual estimate) \\
Comments & Any comment the foresters wish to record \\
Sale & Type of sale \\
\hline
\end{tabular}

\section{MATERIALS AND METHODS}

\subsection{Data collection}

Our project focused on 6000 ha of public forests in the area of Saint-Hubert, Wallonia, Belgium. This forest district, which includes 2500 ha of Norway spruce plantations, suffered heavily from an outbreak of I. typographus in 1991-1992. Information on attacks by the bark beetle was extracted from timber sales for 1988 to 1996 .

In Belgium, timber is sold "standing". Before being felled, trees are individually marked and measured in order to have an estimate of their volume. Each consignment of timber is recorded on a "timber-marking" form that gives the number of trees per circumference category and the estimated height of the trees. Other information includes the tree species, plot location, timber quality and type of felling operation. The quality of the timber is evaluated using qualitative categories combined to a quantitative estimation of its commercial value (Tab. I). Only trees from the same species, quality and felling operation are put in the same consignment and recorded on a given form.

More than 10000 sales records were consulted for the 1988-1996 period. About 1100 forms were selected as corresponding to sales of trees infested by I. typographus. The selection was made using criteria such as the tree species, the quality of timber and the silvicultural operation.

\subsection{Data evaluation}

In order to test the reliability of the data, an evaluation was carried out at several levels. First, a questionnaire was submitted to the local forest officers and was followed by individual interviews in March 1997. Its main purpose was to determine how the officers identified infested trees and how they reported them on the timber-marking forms. It was composed of three main sections considering: (a) the expertise in identifying and recording attacks by I. typographus, (b) the strategy developed for marking and felling the attacked trees and (c) the delays that occurred between the identification of attacks and the removal of infested trees from the forest.
In a second step, the foresters were asked to verify whether the selected forms for 1993-1996 truly corresponded to infested spruces. These forms covered a recent, non-epidemic period for which information could be retrieved from management diaries or remembered relatively easily.

Finally, sales records were compared to the actual field situation. Twenty-five field verifications were made throughout the district between June 1997 and March 2000. Comparisons checked for the presence and localisation of infested trees, their number and the year or flight season they were attacked.

\section{RESULTS}

The questionnaire was sent to the eleven forest officers working for the Saint-Hubert forest district. The survey showed that diagnostic criteria used most frequently to identify attacked trees (Fig. 1) were resin exudates and the presence of brown sawdust on the bark or at the foot of the tree (10 of 11 officers). Resin exudates were also considered by 9 of the 11 officers as the most important symptom for the identification of an infested tree. The yellowing of the crown and the bark falling off in patches were listed by $80 \%$ of the officers as very important symptoms for the identification of attacks. Section two of the questionnaire revealed that two-third of the foresters regularly marked a few seemingly healthy trees around infested individuals, in order to avoid missing an attacked tree without visible symptoms. All marked trees were felled and sold as infested timber. Nearly all of those foresters estimated however that they marked less than $10 \%$ of additional healthy trees. The main finding of the last section of the survey was that most officers ( 8 out of 11) felt it was not always possible to spot infested trees in the same flight season they had been attacked (I. typographus having two flight seasons per year). All of these estimated that the proportion of infested trees not identified within the year of attack was less than $10 \%$; this proportion being no greater during epidemics than during endemic periods. 
Table II. Comparison of records on timber-marking forms with the situation in the field. Field assessments $(\mathrm{N}=25$ sampled sites) checked whether the forms correctly recorded the presence of trees attacked by I. typographus, the number of infested trees, the year and the flight season the trees were attacked.

\begin{tabular}{lcccc}
\hline & Presence & Number of trees & Year & Flight season \\
\hline Number of correct forms & $23(92 \%)$ & $17(68 \%)$ & $21(84 \%)$ & $16(64 \%)$ \\
Number of forms with errors & $2(8 \%)$ & $8(32 \%)$ & $4(16 \%)$ & $9(36 \%)$ \\
\hline
\end{tabular}

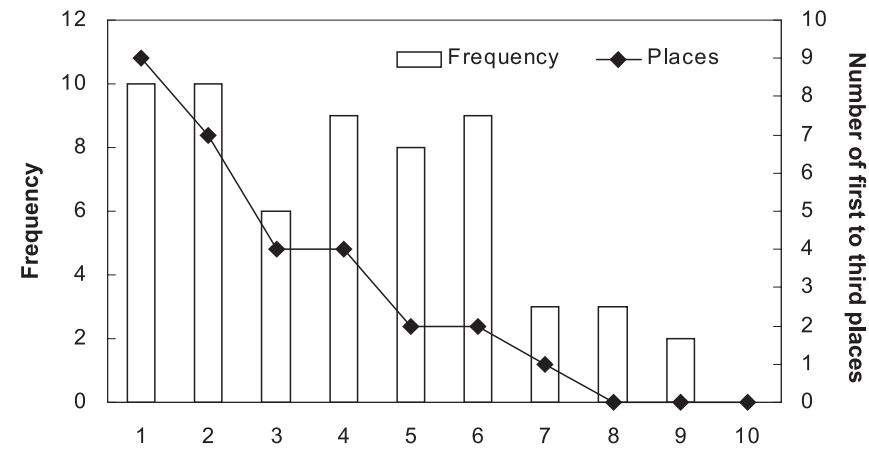

Figure 1. Diagnosis strategies. The bar chart shows the frequency at which particular features were mentioned by the forest officers. The line graph shows the number of times that a criterion was mentioned as one of the three most important identification clues: (1) resin exudates; (2) brown sawdust on bark/at foot of tree; (3) entrance/exit holes; (4) yellow/dead crown; (5) galleries under the bark; (6) bark falling off in patches; (7) dead branches and twigs; (8) yellow shoots and needles; (9) presence of fungi; (10) other. $\mathrm{N}=11$ forest officers.

During their manual verification of the timber sales for 1993 to 1996 , the foresters eliminated about $9 \%$ of the selected forms, which they estimated were not related to sales of infested spruces. Differences in self-confidence were noted between forest officers, depending on the degree of meticulousness of their records in their management diaries.

Results from comparisons between written sales records and the situation in the field are presented in Table II. Trees listed on the timber-marking forms were always correctly located by compartment number but there were some inaccuracies in plot locations within compartments, for example when plot numbers were forgotten. In 23 of the 25 sites, all beetle-marked trees were attacked by I. typographus. The two exceptions concerned trees thought to be infested by the beetle though they actually were healthy (wrongly recorded on the form) and attacked trees missed in an outbreak area (forgotten on the form). Divergences were more important as far as the number of attacked trees were concerned: about one third of the forms listed more infested trees than there really were. When the date of marking was compared to the stage of the attacks, it was observed that trees were often marked only when attacks became detectable from a distance, when the bark started falling from the tree or when the crown turned yellow. Nine $(36 \%)$ of the visited sites hosted trees that had been attacked during the previous flight season - the beetles had already flown away - and in $4(16 \%)$ of the sites, trees had been attacked a year or more earlier (Tab. II).

\section{DISCUSSION}

The questionnaire, interviews and field verifications yielded important information concerning the way damage levels were assessed by the forest officers. The survey showed that resin exudates were considered to be the most important factor for the identification of I. typographus infestations. Following interviews, it appeared that, if most foresters used several symptoms to identify attacked trees, some of them marked trees without any other symptom than resin exudates. The presence of resin exudates, however, is not particularly correlated with I. typographus attacks. It is not even specific to bark beetles, as trees can emit resin as a defence reaction to numerous factors such as insects, fungi, environmental stress and harvesting injuries [3]. Such incorrect diagnosis habits lead to the overestimation of I. typographus damage levels. Other diagnosis criteria regularly used by the officers (Fig. 1) proved to be appropriate for the correct identification of infestations. The overestimation of attacks was further increased by the tendency of some officers to mark a greater number of trees than necessary. The main reason evoked was security: they preferred to deploy a sanitary boundary around the infestation in case some trees did not yet bear visible symptoms. On the other hand, foresters admitted that some trees remained undetected up to one year (or more) after their attack. Several reasons were given for this lack of detection, such as greater spotting difficulties in dense spruce plantations or in plots with low accessibility. The scarcity of clearly visible symptoms during early infestation stages also delayed detection of damage.

The verification procedure of the sales records has to be interpreted cautiously, as the questionnaire and interviews demonstrated that foresters could make mistakes in the identification of infestations. This would be reflected further in their assessment of recorded data. Moreover, some officers were less careful than others in recording observations of attacks in their management diaries and could be unsure in the comparison of their notes to the selected forms. However, the verification procedure usefully highlighted that pre-selected forms corresponding to consignments of small diameter trees, and with no specific comments relating to $I$. typographus attacks, were often related to trees dying of competition in young plantations or to trees attacked by another bark beetle, Pityogenes chalcographus.

As stated by Anderbrant [1], a good monitoring system should be able to answer three questions about the target species: "where does it occur?", "when does it occur?" and "how many insects are there?". This study shows promising possibilities for the use of records from sales of infested timber, at least regarding the first two questions. Information seems to be reliable if summarised per compartment and per year, but not per flight season. However, sales records do not answer the third question. In this study, the attack levels are overestimated, 
as more trees are cut than are actually infested. The reliability of data could probably be improved if standard rules for recording infestations are established. Foresters could also be trained to use appropriate symptoms for the identification of attacks and encouraged not to mark more trees than necessary. A good step has been achieved in this direction, as recording procedures in Wallonia have been changed since the study was carried out. A specific codification is now applied to trees attacked by bark beetles, allowing them to be differentiated unequivocally on the sales records from windthrows or from other dead timber.

Due to its restricted geographical scale, the assessment of forest sales statistics carried out in this study is only valid locally. However, an extension of the study could be carried out relatively easily and would prove extremely useful, not only to scientists but to forest managers as well.

Providing that limitations are clearly established, sales of infested timber could provide a rapid and cost-effective way to estimate past and current infestations. The approach should ideally be complemented by more detailed information from monitoring with pheromone traps or from permanent plot studies. Experience from national inventories has shown that the most important abiotic or biotic epidemics could be uncovered in this way $[5,7]$.

Acknowledgements: The authors wish to thank Ir. Cl. Charue and the forest officers at Saint-Hubert for their enthusiastic collaboration to the project. Funding for this work was provided by a F.R.I.A. research grant to Anne Franklin. J.-C. Grégoire thanks the FNRS for financial support.

\section{REFERENCES}

[1] Anderbrant O., Monitoring pine sawflies with pheromone traps, in: Grodzki W., Knízek M., Forster B. (Eds.), Methodology of forest insect and disease survey in Central Europe, Proceedings of the First Workshop of the IUFRO WP 7.03.10, April 21-24 1998, Ustron-Jaszowiec, Poland, Warszawa, Forest Research Institute (IBL), 1998, pp. 75-79.

[2] Berryman A.A., Population dynamics of the fir engraver, Scolytus ventralis (Coleoptera: Scolytidae). I. Analysis of population behavior and survival from 1964 to 1971, Can. Entomol. 105 (1973) $1465-1488$

[3] Christiansen E., Waring R.H., Berryman A.A., Resistance of conifers to bark beetle attack: searching for general relationships, For. Ecol. Manage. 22 (1987) 89-106.

[4] Forster B., Knizek M., Grodzki W. (Eds.), Methodology of forest insect and disease survey in Central Europe, Proceedings of the Second Workshop of the IUFRO WP 7.03.10, April 20-23, 1999, Sion-Châteauneuf, Switzerland, Birmensdorf, Swiss Federal Institute for Forest, Snow and Landscape Research (WSL), 1999.

[5] Landmann G., Nageleisen L.-M., Flot J.-L., Forest health monitoring on permanent plots considered in combination with forest insect and disease survey results: the French experience, in: Forster B., Knizek M., Grodzki W. (Eds.), Methodology of forest insect and disease survey in Central Europe, Proceedings of the Second Workshop of the IUFRO WP 7.03.10, April 20-23, 1999, SionChâteauneuf, Switzerland, Birmensdorf, Swiss Federal Institute for Forest, Snow and Landscape Research (WSL), 1999, pp. 67-73.

[6] Lecomte H. , Florkin P., Thirion M., L'inventaire des massifs forestiers de la Wallonie: aperçu global de la situation en 1996, Fiche technique no. 9, Ministère de la Région Wallonne, Direction Générale des Ressources naturelles et de l'Environnement, Namur, 1997.

[7] Nevalainen S., Nationwide forest damage surveys in Finland, in Forster B., Knizek M., Grodzki W. (Eds.), Methodology of forest insect and disease survey in Central Europe, Proceedings of the Second Workshop of the IUFRO WP 7.03.10, April 20-23, 1999 , Sion-Châteauneuf, Switzerland, Birmensdorf, Swiss Federal Institute for Forest, Snow and Landscape Research (WSL), 1999, pp. 24-29.

[8] Thatcher R.C., Mason G.N., Hertel G.D., Searcy J.L., Detecting and controlling the southern pine beetle, Southern J. Appl. Forestry, 6 (1982) 153-159.

[9] Worrel R., Damage by the spruce bark beetle in South Norway 1970-1980: A survey, and factors affecting its occurrence, Med. Nor. Inst. Skogforsk. 38 (1983) 1-34. 